\title{
Nipple-Like Focal Distal Esophageal Epidermoid Metaplasia
}

\author{
Vincent Zimmer ${ }^{\mathrm{a}, \mathrm{b}}$ Kai Emrich ${ }^{\mathrm{c}}$ \\ ${ }^{a}$ Department of Medicine, Marienhausklinik St. Josef Kohlhof, Neunkirchen, Germany; ${ }^{b}$ Department of

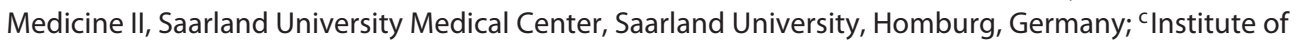 \\ Pathology Saarbrücken-Rastpfuhl, Saarbrücken, Germany
}

\section{Keywords}

Squamous cell carcinoma - Esophageal cancer - Endoscopy · Esophageal epidermoid metaplasia

\section{Metaplasia epidermóide no esófago distal de forma mamilar}

\section{Palavras Chave}

Carcinoma de células escamosas · Neoplasia do esófago · Endoscopia · METAPLASIA epidermóide esofágica

A 65-year-old male patient was admitted to hospital with alcoholic steatohepatitis. He underwent esophagogastroduodenoscopy to assess for upper gastrointestinal (GI) bleeding due to hemoglobin levels of $7.4 \mathrm{~g} / \mathrm{dL}$. While neither an active/potential bleeding source nor esophagogastric varices were to be identified, a tiny, nipple-like, whitish lesion, with an estimated diameter of $1.5 \mathrm{~mm}$, was detected in the distal esophagus $1 \mathrm{~cm}$ above the Z-line (Fig. 1a). To improve visualization and operability during intended forceps removal, we switched to cap-fitted endoscopy with a long, small-diameter cap (Fig. 1b). The lesion was grasped under visual control (Fig. 1c), resulting in a macroscopic complete one-piece resection

karger@karger.com www.karger.com/pjg

Karger"

GOPEN ACCESS (c) 2021 Sociedade Portuguesa de Gastrenterologia. Published by S. Karger AG, Basel

This is an Open Access article licensed under the Creative Commons Attribution-NonCommercial-4.0 International License (CC BY-NC) (http://www.karger.com/Services/OpenAccessLicense), applicable to the online version of the article only. Usage and distribution for commercial purposes requires written permission.
(Fig. 1d). Pathologic evaluation of the targeted biopsy indicated squamous epithelium with hyperorthokeratosis, and a prominent granular layer, resembling the epidermis of the skin (Fig. 1e, f). Overall, the lesion was characterized as epidermoid metaplasia without signs of dysplasia.

Epidermoid metaplasia of the esophagus is rare in endoscopy practice, with only 2 cases $(0.2 \%)$ being reported in 1,048 consecutive esophageal biopsies in the pathology literature [1]. Its distinct pathogenesis has still to be delineated, but chronic irritation, by, for example, alcohol and/or tobacco has been assumed to be contributory factors. Of note, epidermoid metaplasia has to be considered a preneoplastic lesion, such that exclusion of dysplasia requires meticulous endoscopic assessment of the whole esophageal mucosa, and, although not systematically studied and/or in a stricter sense evidence-based, surveillance endoscopies from time to time $[2,3]$. Indeed, we have advised our patient to undergo a repeat upper endoscopy in 12 months. While most reports describe widespread lesions, to the best of our knowledge, this tiny focal lesion represents the smallest ever reported lesion. Albeit purely speculative, the emergence of this lesion could be attributable to defective healing complicating focal esophageal injury, e.g., esophagogastric reflux. 

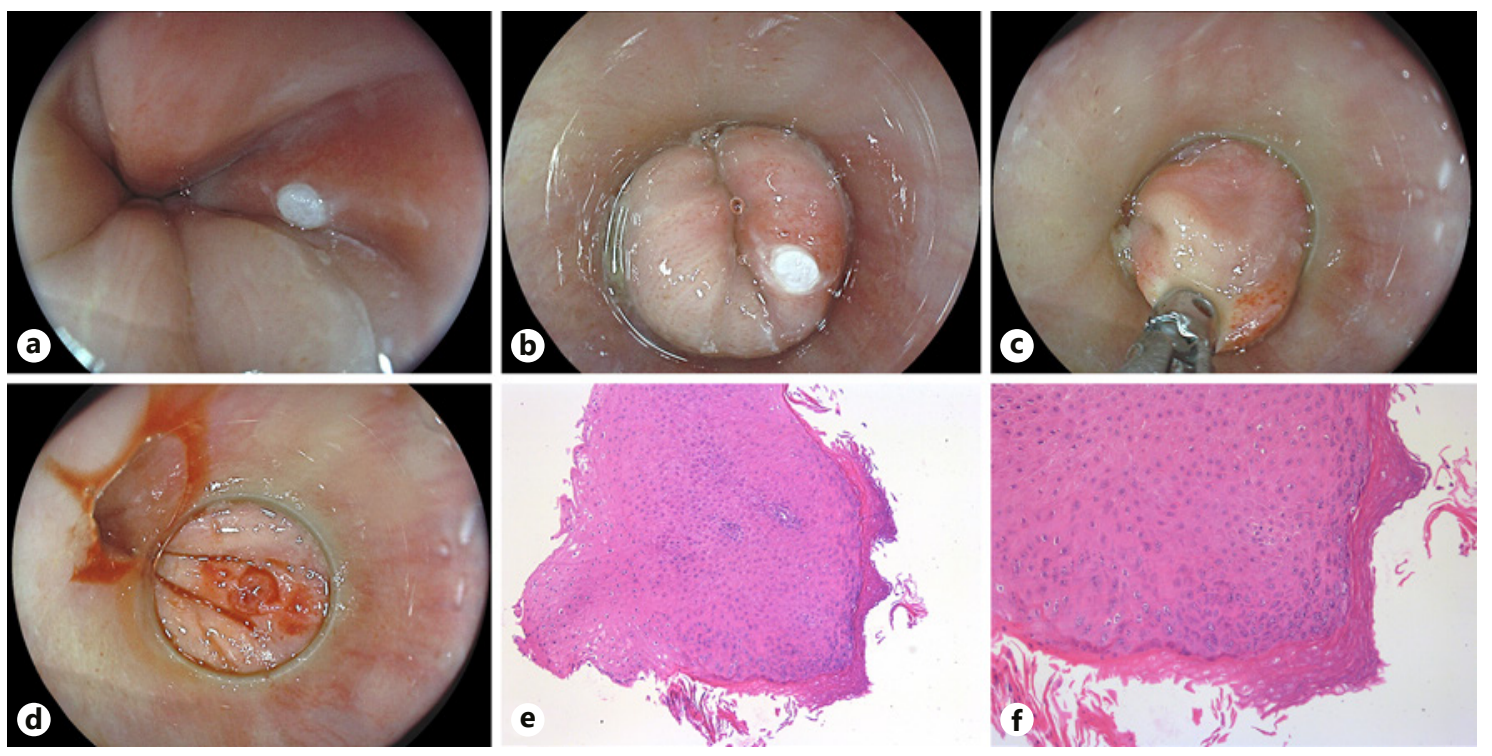

Fig. 1. a Standard endoscopy identified a compact-appearing, flat, elevated, whitish lesion of about $1.5 \mathrm{~mm}$ in size in the distal esophagus $1 \mathrm{~cm}$ above the Z-line. $\mathbf{b}$ Cap-fitted endoscopy likewise confirmed these findings and proved instrumental in the stabilization of the lesion for targeted forceps removal (c). d Post-biopsy assessment indicating macroscopic complete en bloc removal of the lesion. e, $\mathbf{f}$ Pathologic findings were significant for hyperorthokeratosis and a prominent granular layer without dysplasia, reminiscent of the epidermis of the skin ("epidermoid metaplasia”). HE. e $\times 5 . \mathbf{f} \times 10$.

\section{Statement of Ethics}

The patient gave his written informed consent for publication (including the images).

\section{Conflict of Interest Statement}

The author has no conflicts of interest to declare.

\section{Funding Sources}

There was no funding.

\section{Author Contributions}

V.Z.: clinical care, drafting, and finalization of manuscript; K.E.: pathology, revision, and final approval of the manuscript.

\section{References}

1 Cottreau J, Gruchy S, Kamionek M, Lauwers GY, Arnason T. Prevalence of oesophageal epidermoid metaplasia in 1048 consecutive patients and 58 patients with squamous neoplasms. Histopathology. 2016 Jun;68(7):98895.

2 Singhi AD, Arnold CA, Crowder CD, LamHimlin DM, Voltaggio L, Montgomery EA. Esophageal leukoplakia or epidermoid meta- plasia: a clinicopathological study of 18 patients. Mod Pathol. 2014 Jan;27(1):38-43.

3 Singhi AD, Arnold CA, Lam-Himlin DM, Nikiforova MN, Voltaggio L, Canto MI, et al. Targeted next-generation sequencing supports epidermoid metaplasia of the esophagus as a precursor to esophageal squamous neoplasia. Mod Pathol. 2017 Nov;30(11):161321. 